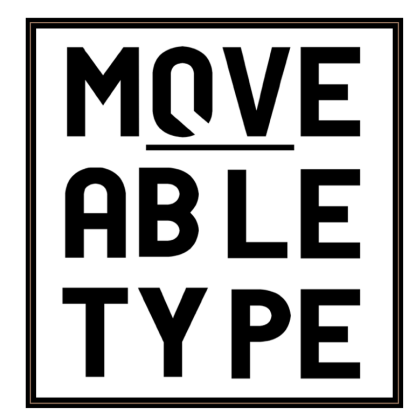

'Grave Reading'

Author: David Prescott-Steed

Source: Moveable Type, Vol.13, 'Ambience' (2021)

DOI: $10.14324 / 111.1755-4527.126$

MoveableType is a Graduate, Peer-Reviewed Journal based in the Department of English at UCL.

(C) 2021 David Prescott-Steed. This is an Open Access article distributed under the terms of the Creative Commons Attribution License (CC-BY)

4.ohttps://creativecommons.org/licenses/by/4.0/, which permits unrestricted use, distribution, and reproduction in any medium, provided the original author and source are credited. 


\section{Grave Reading}

David Prescott-Steed

A little boy shall sadly miss

A silent tear that lasts

As long as time itself

But only two per grave

Please

Read

At rest

Together

With love

Reunited and sleeping

In the garden

Always remembered

Plastic vases

Exit paths

To boundary road. 